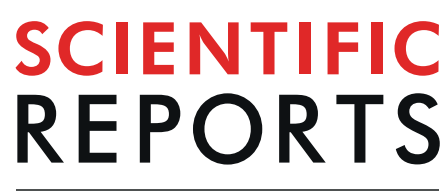

natureresearch

\title{
Melatonin modulates red-ox state and decreases viability of rat pancreatic stellate cells
}

\author{
Antonio Gonzalez $\mathbb{1}^{1 *}$, Matias Estaras ${ }^{1}$, Salome Martinez-Morcillo ${ }^{2}$, Remigio Martinez $\mathbb{1}^{3}$, \\ Alfredo García ${ }^{4}$, Mario Estévez $\mathbb{D}^{5}$, Patricia Santofimia-Castaño ${ }^{6}$, Jose A. Tapia ${ }^{1}$, Noelia Moreno ${ }^{1}$, \\ Marcos Pérez-López ${ }^{2}$, María P. Míguez ${ }^{2}$, Gerardo Blanco-Fernández $\mathbb{D}^{7}$, Diego Lopez-Guerra $\mathbb{D}^{7}$, \\ Miguel Fernandez-Bermejo ${ }^{8}$, Jose M. Mateos ${ }^{8}$, DanielVara ${ }^{8}$, Vicente Roncero ${ }^{9}$ \& Gines M. Salido ${ }^{1}$
}

In this work we have studied the effects of pharmacological concentrations of melatonin $(1 \mu \mathrm{M}-1 \mathrm{mM})$ on pancreatic stellate cells (PSC). Cell viability was analyzed by AlamarBlue test. Production of reactive oxygen species (ROS) was monitored following $\mathrm{CM}-\mathrm{H}_{2}$ DCFDA and MitoSOX Red-derived fluorescence. Total protein carbonyls and lipid peroxidation were analyzed by HPLC and spectrophotometric methods respectively. Mitochondrial membrane potential $\left(\psi_{m}\right)$ was monitored by TMRM-derived fluorescence. Reduced (GSH) and oxidized (GSSG) levels of glutathione were determined by fluorescence techniques. Quantitative reverse transcription-polymerase chain reaction was employed to detect the expression of Nrf2-regulated antioxidant enzymes. Determination of SOD activity and total antioxidant capacity (TAC) were carried out by colorimetric methods, whereas expression of SOD was analyzed by Western blotting and RT-qPCR. The results show that melatonin decreased PSC viability in a concentrationdependent manner. Melatonin evoked a concentration-dependent increase in ROS production in the mitochondria and in the cytosol. Oxidation of proteins was detected in the presence of melatonin, whereas lipids oxidation was not observed. Depolarization of $\psi_{\mathrm{m}}$ was noted with $1 \mathrm{mM}$ melatonin. A decrease in the GSH/GSSG ratio was observed, that depended on the concentration of melatonin used. A concentration-dependent increase in the expression of the antioxidant enzymes catalytic subunit of glutamate-cysteine ligase, catalase, NAD(P)H-quinone oxidoreductase 1 and heme oxygenase-1 was detected in cells incubated with melatonin. Finally, decreases in the expression and in the activity of superoxide dismutase were observed. We conclude that pharmacological concentrations melatonin modify the redox state of PSC, which might decrease cellular viability.

It is nowadays increasing the focus of research on the role of pancreatic stellate cells (PSC) in the physiology and the pathophysiology of the pancreas. PSC comprise of a rather small cell population of the organ. Under normal conditions PSC remain quiescent, but become activated in disease. Activated PSC are responsible for the progressive fibrosis and for the accumulation of extracellular matrix that occurs in severe pancreatic disorders such as chronic pancreatitis and pancreatic cancer ${ }^{1,2}$. Therefore, it is thought that activated PSC are involved in tumor progression and chemoresistance. In this regard, PSC contribute to stromal or fibrotic reaction by the release of matrix components, release signaling molecules that act on neighboring cells to modulate their proliferation and tissue growth within cancer ${ }^{3}$. Unraveling the mechanisms underlying growth and proliferation of PSC is of major relevance for the understanding of pancreatic diseases. In this line, it is tempting to find drugs whose anti-inflammatory, anti-fibrotic and/or anti-proliferative actions could be used in therapy.

${ }^{1}$ Institute of Molecular Pathology Biomarkers, University of Extremadura, Caceres, Spain. ${ }^{2}$ Unit of Toxicology, Veterinary Faculty, University of Extremadura, Caceres, Spain. ${ }^{3}$ Department of Animal Health, Veterinary Faculty, University of Extremadura, Caceres, Spain. ${ }^{4}$ Department of Animal Production, CICYTEX-La Orden, Guadajira, Badajoz, Spain. ${ }^{5}$ IPROCAR Research Institute, Food Technology, University of Extremadura, 10003, Cáceres, Spain. ${ }^{6}$ Centre de Recherche en Cancérologie de Marseille, INSERM U1068, CNRS UMR 7258, Aix-Marseille Université and Institut Paoli-Calmettes, Parc Scientifique et Technologique de Luminy, Marseille, France. ${ }^{7}$ Hepatobiliary-Pancreatic Surgery and Liver Transplant Unit, Infanta Cristina Hospital, Badajoz, Spain. ${ }^{8}$ Department of Gastroenterology, San Pedro de Alcantara Hospital, Caceres, Spain. ${ }^{9}$ Unit of Histology and Pathological Anatomy, Veterinary Faculty, University of Extremadura, Caceres, Spain. *email: agmateos@unex.es 
Melatonin (N-acetyl-5-methoxytryptamine) is a compound that is produced mainly, but not exclusively, in the pineal gland. Initially, it was considered a hormone with key roles in the regulation of circadian rhythms, conveying physiological and neuroendocrine functions within the body. However, melatonin is also produced in other parts of the organism, as for example retina, Harderian gland, gastrointestinal tract, testes and lymphocytes where it can induce local effects ${ }^{4}$. The compound exerts its actions acting through its specific receptors or directly. Melatonin can bind to cellular membrane MT1- and MT2-type receptors, or can interact with intracellular proteins, as for example nuclear receptor ROR/RZR, quinone reductase 2 (termed MT3 type receptor) and calmodulin $^{5-8}$. Beside its actions as a circadian regulator, especially of reproduction, melatonin also works as free radical scavenger, through potentiation of antioxidant defenses or via immune modulation, thereby exerting protective roles on cell physiology ${ }^{8}$. On the contrary, melatonin also induces cell death ${ }^{8,9}$. Interestingly, all these effects are cell- and context-dependent ${ }^{8}$. With time, widespread attention on the effects of melatonin on cellular physiology and, especially, on its ability to control cell proliferation in cancer has emerged. Melatonin induces antitumor effects in different tissues ${ }^{10-13}$, including the pancreas ${ }^{14,15}$. The anticarcinogenic effects of melatonin involve different mechanisms, as for example apoptosis and cancer immunity. In addition, melatonin diminishes autophagy, metastasis and angiogenesis, leading in general to a decrease of proliferation of malignant cells ${ }^{16}$.

As mentioned above, PSC depict an important role as components of the tumor microenvironment and have emerged as key modulators in the context of tissue injury. In this regard, we have shown that melatonin modulates proliferation of murine ${ }^{17}$ and human $\mathrm{PSC}^{18}$. Our previous results showed that melatonin induced $\mathrm{Ca}^{2+}$ mobilization from intracellular pools and activation of key components of the mitogen-activated protein kinases (MAPKs) family. In addition, in human PSC a decrease in the GSH/GSSG ratio was observed, which could compromise cellular antioxidant defenses and induce prooxidant conditions that could diminish cell survival. Therefore, melatonin might be a compound with putative parallel effects on the cells forming part of a growing tumor, controlling their proliferation.

In the present study we aimed at identifying new actions of melatonin on the pancreas which might highlight the compound as potential candidate in therapy. We have continued our former studies to further investigate the ways by which melatonin could exert its effects on PSC to control their proliferation.

\section{Materials and Methods}

Pancreatic tissues and chemicals. Pancreatic tissues used in this study were obtained from newborn Wistar rats (one week). Animals employed have been purchased from the animal house of the University of Extremadura (Caceres, Spain). Animals handling, methods and experimental protocols were approved by, and were carried out according to, the University Ethical Committee (reference 57/2016) and by the Institutional Committee of the Junta de Extremadura (reference 20160915). Additionally, all methods and the experimental protocols were performed in accordance with the relevant guidelines and regulations of the Ethical Committee for Animal Research of the University of Extremadura and with the Institutional Committee of the Junta de Extremadura (law 32/2007 and RD 53/2013).

Most chemicals and reagents used for the present work were purchased from Sigma-Aldrich (Merck, Madrid, Spain) and AbD serotec (BioNova Científica, Madrid, Spain). The enzyme collagenase CLSPA for digestion of the pancreas was purchased from Worthington Biochemical Corporation (Labclinics, Madrid, Spain). The components for the preparation of culture medium and the fluorescent probes used were obtained from Invitrogen (Fisher Scientific Inc., Madrid, Spain) and from BioWhittaker (Lonza, Basel, Switzerland). Plastic materials for cell culture were purchased from Thermo Fisher Sci. (Madrid, Spain). Materials and reagents for Western blotting were purchased from Bio-Rad (Madrid, Spain) and from Cell Signaling Technology (C-Viral, Madrid, Spain). Superoxide dismutase (SOD) activity, total antioxidant capacity (TAC) kits were purchased from BioVision (Deltaclon S.L., Madrid, Spain).

The antibodies and primers used were purchased from Thermo Scientific (Fisher Scientific Inc., Madrid, Spain), Sigma-Aldrich (Merck, Madrid, Spain) and Santa Cruz Biotechnologies Inc. (Quimigen S.L., Madrid, Spain).

Pancreatic stellate cells cultures. PSC were prepared and cultured using established methods ${ }^{17}$. After preparation of cells suspension, small aliquots were seeded on polystyrene plates for cell culture. Culture medium consisted of medium 199, plus $4 \%$ horse serum, $10 \% \mathrm{FBS}, 0.1 \mathrm{mg} / \mathrm{mL}$ streptomycin, $100 \mathrm{IU}$ penicillin and $1 \mathrm{mM}$ $\mathrm{NaHCO}_{3}$. The cells were grown under constant temperature $\left(37^{\circ} \mathrm{C}\right)$ and $\mathrm{CO}_{2}(5 \%)$. Confluence $(90-95 \%)$ was reached after eight-ten days of culture.

Study of cell viability. Cells were treated with different stimuli for $48 \mathrm{~h}$. Determination of cell viability was carried out according to previous techniques ${ }^{19}$. A plate reader was used to monitor absorbance (VariosKan Lux 3020-205, Thermo Sci., Vantaa, Finland). The viability of cells subjected to stimuli was compared with that of control cells (non-stimulated). Data show the change in cell viability expressed as the mean in percentage \pm S.E.M. (n) with respect to non-stimulated cells ( $\mathrm{n}$ is the number of experiments carried out).

Detection of reactive oxygen species (ROS) generation. ROS generation was monitored employing methods used in or laboratory ${ }^{20}$. Cells were detached and loaded with $\mathrm{CM}-\mathrm{H}_{2}$ DCFDA $(10 \mu \mathrm{M})$ or with MitoSOX Red $(2.5 \mu \mathrm{M})$. Next, cells were incubated with stimuli during $1 \mathrm{~h}$. For detection of changes in the red-ox state cells were excited at $530 \mathrm{~nm}$ and fluorescence emitted was detected at $590 \mathrm{~nm}$ for CM- $\mathrm{H}_{2}$ DCFDA, whereas for cells loaded with MitoSOX red excitation at $510 \mathrm{~nm}$ with detection at 580 were employed. A spectrofluorimeter was used to monitor fluorescence (VariosKan Lux 3020-205, Thermo Sci., Vantaa, Finland). Results show the mean increase of fluorescence expressed in percentage \pm SEM (n) with respect to non-stimulated cells, where $n$ is the number of independent experiments, as described previously ${ }^{20}$. 
Detection of protein Carbonyls (Allysine). Cells were incubated during $1 \mathrm{~h}$ with stimuli and, thereafter, were lysed for analysis. Detection of protein carbonyls was performed according to the methods described by Villaverde et al. ${ }^{21}$. In brief, five hundred $\mu \mathrm{L}$ of each sample were treated with cold $10 \%$ trichloroacetic acid (TCA) solution. After centrifugation $\left(600 \times g\right.$ for $5 \mathrm{~min}$ at $\left.4^{\circ} \mathrm{C}\right)$ the supernatants were removed and the pellets were sequentially incubated with a solution containing $0.5 \mathrm{~mL} 250 \mathrm{mM}$ 2-(N-morpholino) ethanesulfonic acid (MES) buffer $\mathrm{pH} 6.0$ containing $1 \mathrm{mM}$ diethylenetriaminepentaacetic acid (DTPA), a solution containing $0.5 \mathrm{~mL} 50 \mathrm{mM}$ ABA in $250 \mathrm{mM}$ MES buffer $\mathrm{pH} 6.0$ and a solution containing $0.25 \mathrm{~mL} 100 \mathrm{mM} \mathrm{NaBH}_{3} \mathrm{CN}$ in $250 \mathrm{mM}$ MES buffer $\mathrm{pH}$ 6.0. Next, samples were treated with a cold $50 \%$ TCA solution and centrifuged at $(1200 \times \mathrm{g}$ for $10 \mathrm{~min})$. The pellets were then washed twice with $10 \%$ TCA and diethyl ether-ethanol (1:1). Finally, the pellet was treated with $6 \mathrm{M} \mathrm{HCl}$ and kept in an oven at $110^{\circ} \mathrm{C}$ for $18 \mathrm{~h}$ until completion of hydrolysis. Thereafter, the samples were dried in vacuo and the generated residue was reconstituted with $200 \mu \mathrm{L}$ of milliQ water and filtered for HPLC analysis using a Shimadzu 'Prominence' HPLC apparatus (Shimadzu Corporation, Japan). The elutes were monitored with excitation and emission wavelengths set at 283 and $350 \mathrm{~nm}$, respectively. Standards $(0.1 \mu \mathrm{L})$ were run and analysed under the same conditions. The nmol of allysine per mg of protein were calculated. Results are expressed as percentage $\pm \operatorname{SEM}(\mathrm{n})$ with respect to non-stimulated cells, where $\mathrm{n}$ is the number of independent experiments.

Analysis of thiobarbituric-reactive substances. Cells were incubated during $1 \mathrm{~h}$ with stimuli and, thereafter, were lysed for analysis. Malondialdehyde (MDA) and other thiobarbituric-reactive substances (TBARS) were measured, by adding $500 \mu \mathrm{L}$ thiobarbituric acid $(0.02 \mathrm{M})$ and $500 \mu \mathrm{L}$ trichloroacetic acid $(10 \%)$ to $200 \mu \mathrm{L}$ of a sample from each treatment. Next, the mixture was incubated for $20 \mathrm{~min}$ at $90^{\circ} \mathrm{C}$. After cooling, a 5 min centrifugation at $600 \times g$ was made and the absorbance of supernatant was measured at $532 \mathrm{~nm}$ employing a plate reader (VariosKan Lux 3020-205, Thermo Sci., Vantaa, Finland). The mg/L of TBARS in each sample were calculated. Results are expressed as percentage \pm SEM (n) with respect to non-stimulated cells, where $n$ is the number of independent experiments.

Determination of mitochondrial membrane potential. Changes in mitochondrial membrane potential $\left(\psi_{\mathrm{m}}\right)$ were recorded using the dye TMRM as described previously ${ }^{22}$. Cells were incubated during $1 \mathrm{~h}$ in the presence of stimuli. A decrease in TMRM fluorescence reflects depolarization of $\psi_{\mathrm{m}}$. Fluorescence was measured employing a spectrofluorimeter (VariosKan Lux 3020-205, Thermo Sci., Vantaa, Finland). The experiments were carried out employing batches of cells obtained from different preparations. The increase of fluorescence with respect to non-stimulated cells was calculated and expressed in percentage as the mean \pm SEM ( $n$ ) ( $n$ is the number of experiments).

Determination of glutathione levels. The changes in the levels of reduced (GSH) and oxidized (GSSG) glutathione were determined using methods described previously ${ }^{18}$. Cells were incubated during $4 \mathrm{~h}$ with the different stimuli assayed. A spectrofluorimeter (Tecan Infinite M200, Grödig, Austria) was employed to detect GSH or GSSG at $350 \mathrm{~nm} / 420 \mathrm{~nm}$ (excitation/emission) respectively. For quantification, standard curves of GSH and GSSG were used. Normalization was carried out based on the total protein concentration in each sample s. $^{23}$ A standard curve was prepared using bovine serum albumin. The experiments were carried out employing batches of cells obtained from different preparations.

Data are shown as the mean increase in GSH/GSSG ratio expressed in percentage \pm SEM (n) with respect to non-stimulated cells, where $\mathrm{n}$ is the number of independent experiments.

Quantitative reverse transcription-polymerase chain reaction (RT-qPCR) analysis. This procedure was carried out as previously described ${ }^{24}$. PSC in culture were incubated during $4 \mathrm{~h}$ with different stimuli and lysed. Total RNA samples were purified using a commercially available kit (Sigma, Madrid, Spain). The Power SYBR Green RNA-to- $\mathrm{C}_{\mathrm{T}}$ 1-Step kit (Applied Biosystems, Township, USA) was used. Reverse transcription was performed for $30 \mathrm{~min}$ at $48^{\circ} \mathrm{C}$, and PCR conditions were $10 \mathrm{~min}$ at $95^{\circ} \mathrm{C}$ followed by 40 cycles of $15 \mathrm{~s}$ at $95^{\circ} \mathrm{C}$ plus $1 \mathrm{~min}$ at $55^{\circ} \mathrm{C}$ using the following primers:

Gclc:5'-GGCACAAGGACGTGCTCAAGT-3 ${ }^{\prime}$ and 5'-TGCAGAGTTTCAAGAACATCG-3'

Cat: $5^{\prime}$-ACTTTGAGGTCACCCACGAT-3' and 5'-AACGGCAATAGGGGTCCTCTT-3'

Ho-1:5'-AGCACAGGGTGACAGAAGAG- ${ }^{\prime}$ and $5^{\prime}$-GAGGGACTCTGGTCTTTGTG- ${ }^{\prime}$

Nqo-1:5'-GGGGACATGAACGTCATTCTCT- $3^{\prime}$ and $5^{\prime}$-AAGACCTGGAAGCCACAGAAGC- $3^{\prime}$

Gapdh:5'-GGGTGTGAACCACGAGAAAT- $3^{\prime}$ and $5^{\prime}$-CCTTCCACGATGCCAAAGTT-3'

SOD1: $5^{\prime}$-GGGGACAATACACAAGGCTGTA-3' and 5'-CAGGTCTCCAACATGCCTCT-3'

SOD2: 5'-GTGGAGAACCCAAAGGAGAG-3' and 5'-GAACCTTGGACTCCCACAGA-3'

The mRNA abundance of each transcript was normalized to the Gapdh mRNA abundance obtained in the same sample. The relative mRNA levels were calculated using the $\Delta \Delta \mathrm{Ct}$ method, and were expressed as the fold change between sample and calibrator. The experiments were carried out employing batches of cells obtained from different preparations.

Determination of SOD activity. This procedure was carried out using a commercially available kit from BioVision. Stimuli were added to the cells and were incubated during $1 \mathrm{~h}$. Thereafter SOD activity was determined following the manufacturer's directions. The sensitive SOD assay kit utilizes WST-1 that produces a water-soluble formazan dye upon reduction with superoxide anion.

The activity of SOD can be determined by a colorimetric method. Absorbance at $450 \mathrm{~nm}$ of the samples was measured employing a spectrofluorimeter (VariosKan Lux 3020-205, Thermo Sci., Vantaa, Finland). The experiments were carried out employing batches of cells obtained from different preparations. Results show the mean 


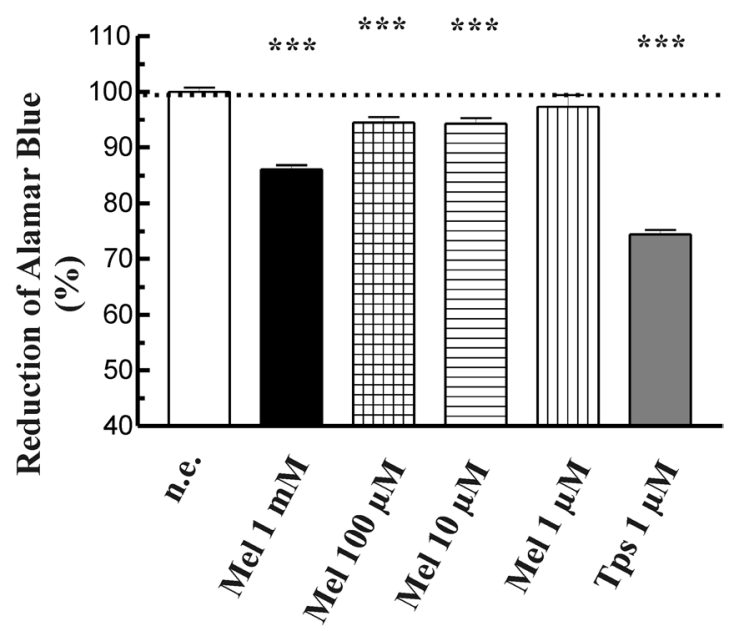

Figure 1. Analysis of PSC viability. Cell viability was analyzed studying AlamarBlue reduction by viable cells. Cells were incubated during $48 \mathrm{~h}$ in the presence of melatonin (Mel; $1 \mathrm{mM}, 100 \mu \mathrm{M}, 10 \mu \mathrm{M}$ or $1 \mu \mathrm{M}$ ) or thapsigarging (Tps, $1 \mu \mathrm{M}$ ) and viability was compared with that of cells in the absence of stimulus (control). In the graph, a dotted line represents the viability of control cells (non-treated cells). Histograms are representative of three independent experiments (n.e.,non-stimulated cells; Mel, melatonin; Tps, thapsigargin; $* * * P<0.001$ vs non-stimulated cells).

change of absorbance expressed in percentage \pm SEM (n) with respect to non-stimulated cells, where $n$ is the number of independent experiments.

Determination of total antioxidant capacity. Total antioxidant capacity (TAC) was determined using a commercially available kit from BioVision, following manufacturer's directions. Absorbance at $570 \mathrm{~nm}$ of the sample was measured employing a plate reader (CLARIOstar Plus, BMG Labtech., C-Viral, Madrid, Spain). Results show the mean change of absorbance expressed in percentage \pm SEM (n) with respect to non-stimulated cells, where $\mathrm{n}$ is the number of independent experiments.

Western blotting analysis. Western blotting was performed using previously described methods ${ }^{14}$. Cells in culture were incubated in the presence of different stimuli during $1 \mathrm{~h}$ and lysed. Bradford's method was used for quantification of the protein content of lysates ${ }^{23}$. Protein lysates $(12 \mu \mathrm{g} / \mathrm{lane})$ of each sample were separated by SDS-PAGE, using $10 \%$ polyacrylamide gels, and were transferred to nitrocellulose membranes. Specific primary and the corresponding IgG-HRP conjugated secondary antibody were used for detection of proteins. Quantification of the intensity of the bands which appear was performed using the software ImageJ (http://imagej. nih.gov/ij/). The experiments were carried out employing batches of cells obtained from different preparations. Values are expressed as the mean \pm SEM of normalized values expressed as $\% v s$ control (non-stimulated) cells.

Statistical analysis. Statistical analysis of data was performed by one-way analysis of variance (ANOVA) followed by Tukey post hoc test, and only $P$ values $<0.05$ were considered statistically significant. For individual comparisons and statistics between individual treatments we employed the Student's $t$ test, and only $P$ values $<0.05$ were considered statistically significant.

\section{Results}

Effects of melatonin on cell viability. It has been suggested that melatonin modulates cell viability of different cellular types ${ }^{9,14,25,26}$, including PSC ${ }^{17,18}$. At this point it was of interest to corroborate the effect of melatonin on cell viability. Thus, PSC were incubated in the absence (non-treated cells) or in the presence of $1 \mathrm{mM}, 100 \mu \mathrm{M}$, $10 \mu \mathrm{M}$ or $1 \mu \mathrm{M}$ melatonin, and cell viability was evaluated after $48 \mathrm{~h}$ of culture. The viability of cells that had been incubated in the presence of melatonin was compared with that of non-treated cells.

Cell viability dropped in the presence of $10 \mu \mathrm{M}$ to $1 \mathrm{mM}$ of melatonin (Fig. 1). A maximal effect was noted with $1 \mathrm{mM}$ melatonin. Separate batches of cells were treated with $1 \mu \mathrm{M}$ thapsigargin (Tps), which served as control for cell death ${ }^{27}$. In the presence of Tps a strong decrease in cell viability was observed.

Effect of melatonin on cellular oxidative state. It has been suggested the melatonin may exert a pro-oxidant action that could underlie its antiproliferative actions ${ }^{28}$. To study this possibility we analyzed the effect of melatonin on ROS production. For this purpose PSC were loaded with the ROS-sensitive fluorescent dyes CM- $\mathrm{H}_{2} \mathrm{DCFDA}$ or MitoSOX Red. Thereafter, cells were incubated during $1 \mathrm{~h}$ with melatonin $(1 \mathrm{mM}, 100 \mu \mathrm{M}, 10 \mu \mathrm{M}$ or $1 \mu \mathrm{M})$. The compound evoked a concentration-dependent increase in ROS production both in the cytosol and in the mitochondria. Hydrogen peroxide $(100 \mu \mathrm{M})$ was used as a control of oxidation. For this purpose the oxidant was added to the cells, which were then incubated during $1 \mathrm{~h}$. In the presence of hydrogen peroxide a statistically significant increase in dye-derived fluorescence was observed, reflecting an increase in oxidation (Fig. 2A,B). 
A

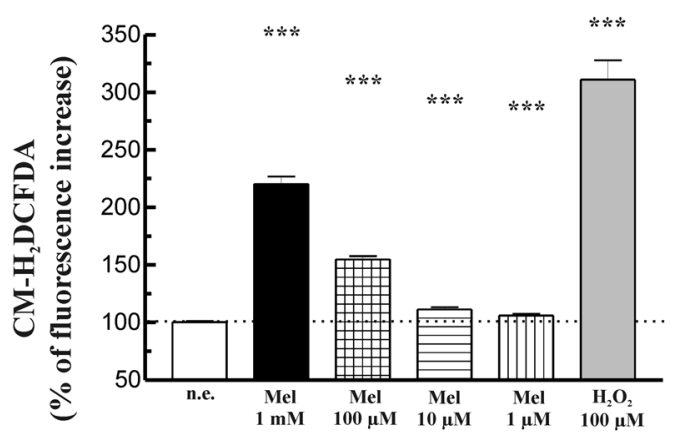

C

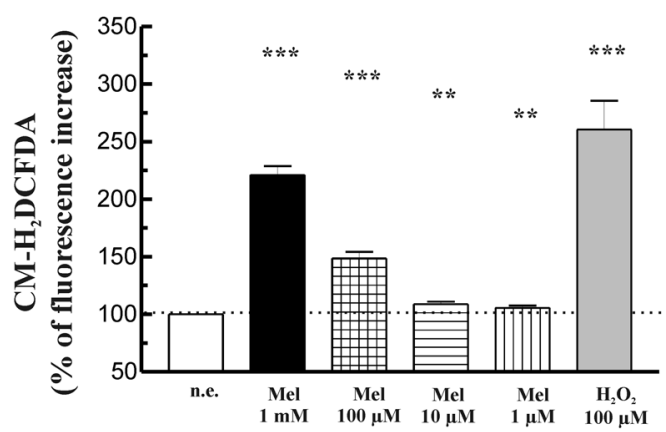

B

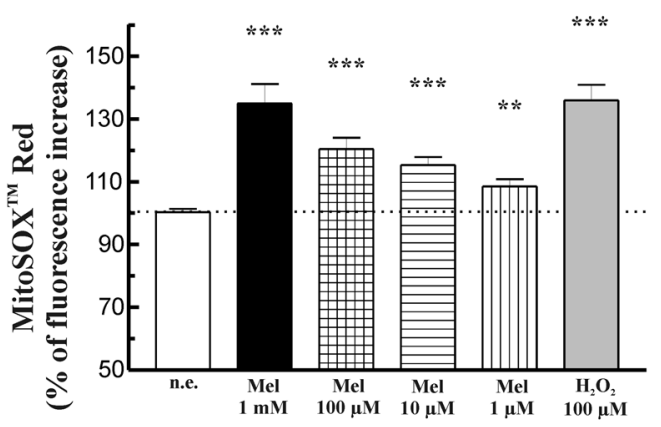

D

$\mathrm{Ca}^{2+}$-free medium

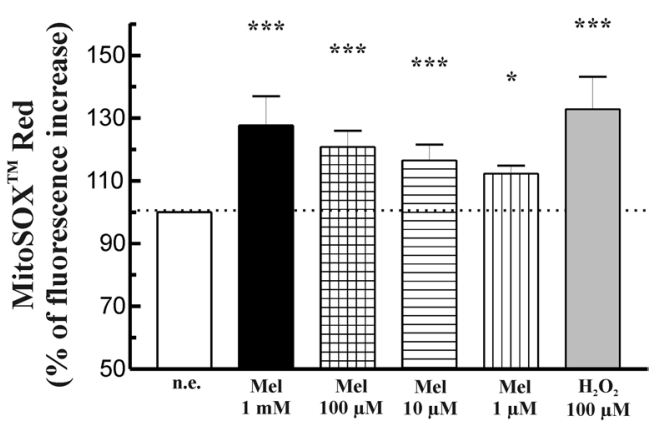

Figure 2. Generation of ROS in response to melatonin. (A) Cells were loaded with the red-ox-sensitive dye $\mathrm{CM}-\mathrm{H}_{2}$ DCFDA and were challenged with different concentrations of melatonin $(1 \mathrm{mM}, 100 \mu \mathrm{M}, 10 \mu \mathrm{M}$ or $1 \mu \mathrm{M})$. As a control, cells were incubated in the presence of $100 \mu \mathrm{M}$ hydrogen peroxide $\left(\mathrm{H}_{2} \mathrm{O}_{2}\right)$. (B) Cells were loaded with the mitochondrial superoxide indicator MitoSOX Red and were incubated in the presence of melatonin $(1 \mathrm{mM}, 100 \mu \mathrm{M}, 10 \mu \mathrm{M}$ or $1 \mu \mathrm{M})$. Separated batches of cells were incubated with $100 \mu \mathrm{M}$ hydrogen peroxide $\left(\mathrm{H}_{2} \mathrm{O}_{2}\right)$. (C and D) Cells, loaded with either of the mentioned dyes, were challenged with melatonin in the absence of $\mathrm{Ca}^{2+}$ in the extracellular medium (medium containing $0.5 \mathrm{mM}$ EGTA). The bars show the mean increase of dye-derived fluorescence expressed in percentage \pm SEM with respect to control (non-stimulated) cells. A horizontal dotted line represents the value observed in non-stimulated cells. Results are representative of six independent experiments (n.e., non-stimulated cells; Mel, melatonin; $* P<0.05$; $* * P<0.01$; $* * * P<0.001$ $v s$ non-stimulated cells).

Increases of cellular calcium $\left(\mathrm{Ca}^{2+}\right)$ have been related with ROS generation and with pancreatic disease ${ }^{22,29}$. In a former work we have shown that melatonin induces mobilization of $\mathrm{Ca}^{2+}$ in $\mathrm{PSC}^{17}$. In order to check whether ROS generation in response to melatonin was dependent on $\mathrm{Ca}^{2+}$, we performed a series of experiments in which PSC were challenged in the absence of extracellular $\mathrm{Ca}^{2+}$ (medium containing $0.5 \mathrm{mM}$ EGTA). Under these conditions ROS production evoked by melatonin did not differ from that observed in the presence of $\mathrm{Ca}^{2+}$ (Fig. 2C,D).

In order to investigate whether the increase in ROS production was accompanied by lipid and/or protein oxidation, the effect of melatonin on protein carbonyl levels and on TBARS were assayed. For this purpose, cells were incubated during $1 \mathrm{~h}$ in the presence of melatonin $(1 \mathrm{mM}, 100 \mu \mathrm{M}, 10 \mu \mathrm{M}$ or $1 \mu \mathrm{M}) . \mathrm{H}_{2} \mathrm{O}_{2}(100 \mu \mathrm{M})$ was used as control. We observed a concentration-dependent increase in the total protein carbonyls content in cells treated with melatonin in comparison with that noted in non-stimulated cells. A maximal effect was observed in response to $1 \mathrm{mM}$ melatonin (Fig. 3A). However, no statistically significant changes were detected in the levels of TBARS (Fig. 3B). Treatment of cells with $\mathrm{H}_{2} \mathrm{O}_{2}(100 \mu \mathrm{M})$ induced statistically significant increases in both total protein carbonyls and TBARS (Fig. 3A,B).

Effect of melatonin on mitochondrial membrane potential. It has been suggested that oxidative stress and changes in $\psi_{\mathrm{m}}$ are closely related ${ }^{30}$. In order to analyze whether melatonin induces changes in $\psi_{\mathrm{m}}$, we performed a series of experiments in which PSC were loaded with the mitochondria-specific voltage-sensitive dye TMRM. The cells were then incubated during $1 \mathrm{~h}$ in the presence of melatonin $(1 \mathrm{mM}, 100 \mu \mathrm{M}, 10 \mu \mathrm{M}$ or $1 \mu \mathrm{M})$. We could only observe a statistically significant decrease in $\psi_{\mathrm{m}}$ in cells treated with $1 \mathrm{mM}$ melatonin. No detectable changes in $\psi_{\mathrm{m}}$ were noted in response to the other concentrations of melatonin employed. As a control, different batches of cells were incubated in the presence of the mitochondrial uncoupler CCCP ${ }^{22,31}$. In the presence of CCCP (100 nM) a statistically significant decrease in $\psi_{\mathrm{m}}$ was detected (Fig. 4). 


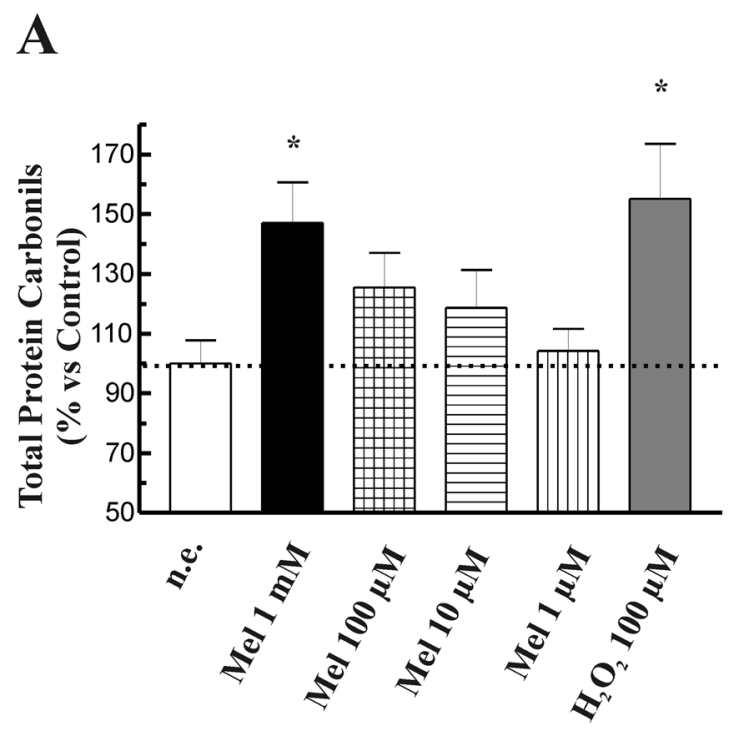

B

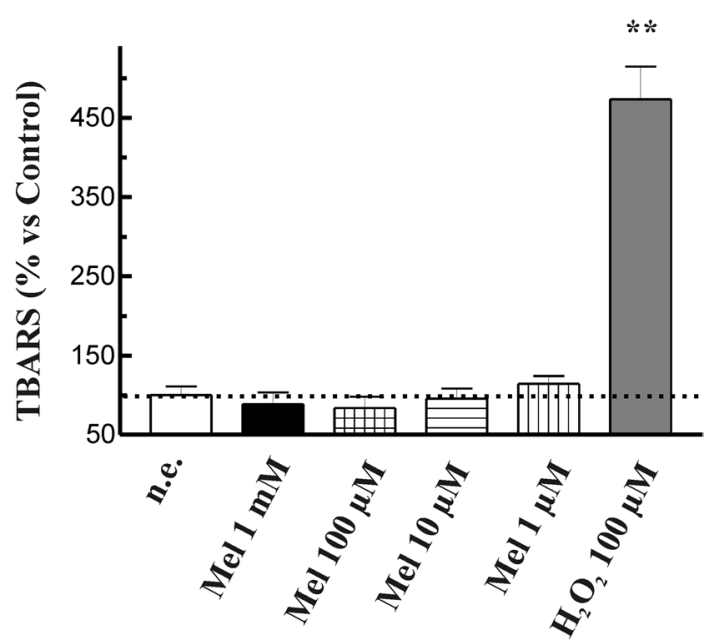

Figure 3. Effect of melatonin on protein and lipid oxidation. PSC were incubated during $1 \mathrm{~h}$ in the presence of melatonin $(1 \mathrm{mM}, 100 \mu \mathrm{M}, 10 \mu \mathrm{M}$ or $1 \mu \mathrm{M})$, and the effect on total protein carbonyls (A) or TBARS (B) were assayed. $100 \mu \mathrm{M} \mathrm{H}_{2} \mathrm{O}_{2}$ was used as control of oxidation. The bars show the mean change expressed in percentage \pm SEM with respect to control (non-stimulated) cells. A horizontal dotted line represents the value observed in non-stimulated cells. Results are representative of six independent experiments (n.e., non-stimulated cells; Mel, melatonin; $\mathrm{H}_{2} \mathrm{O}_{2}$, hydrogen peroxide; $* P<0.05$; $* * P<0.01$ vs non-stimulated cells).

Effect of melatonin on glutathione levels. Glutathione represents a major antioxidant defense against oxidative stress $^{32}$. Because we had observed ROS production in the presence of the melatonin, it was of interest to test its effect on the glutathione system in PSC. Therefore, cells were incubated during $4 \mathrm{~h}$ in the presence of melatonin $(1 \mathrm{mM}, 100 \mu \mathrm{M}, 10 \mu \mathrm{M}$ or $1 \mu \mathrm{M})$ and the levels of GSH and GSSG were analyzed. We observed a concentration-dependent decrease in GSH/GSSG ratio in cells treated with melatonin in comparison with that noted in non-stimulated cells. A maximal effect was observed in response to $1 \mathrm{mM}$ or $100 \mu \mathrm{M}$ melatonin. A slight decrease in GSH/GSSG ratio was observed in response to $10 \mu \mathrm{M}$ melatonin, which was not statistically significant. Whereas we did not detect changes in GSH/GSSG ratio in cells treated with $1 \mu \mathrm{M}$ melatonin (Fig. 5A).

Effect of melatonin on Nrf2-dependent antioxidant enzymes. Nrf2 is a transcription factor that enhances the expression of a multitude of antioxidant and phase II enzymes, which regulate redox homeostasis ${ }^{33}$. The results shown above indicate that melatonin induces changes in the redox status of PSC. Therefore, we decided to study whether melatonin could stimulate the transcriptional activation of certain antioxidant enzymes through the activation of Nrf2. For this purpose PSC were incubated during $4 \mathrm{~h}$ in the presence of melatonin $(1 \mathrm{mM}, 100 \mu \mathrm{M}, 10 \mu \mathrm{M}$ or $1 \mu \mathrm{M})$ and RT-qPCR of the relative mRNA abundance was performed. Melatonin evoked statistically significant increases in the expression of GCLc, CAT, NQO1 and HO-1 (Fig. 5B-D). As a control, cells were incubated in the presence of $\mathrm{H}_{2} \mathrm{O}_{2}(100 \mu \mathrm{M})$, a known Nrf2 activator ${ }^{34}$. The oxidant increased the expression of all four antioxidant enzymes studied. 


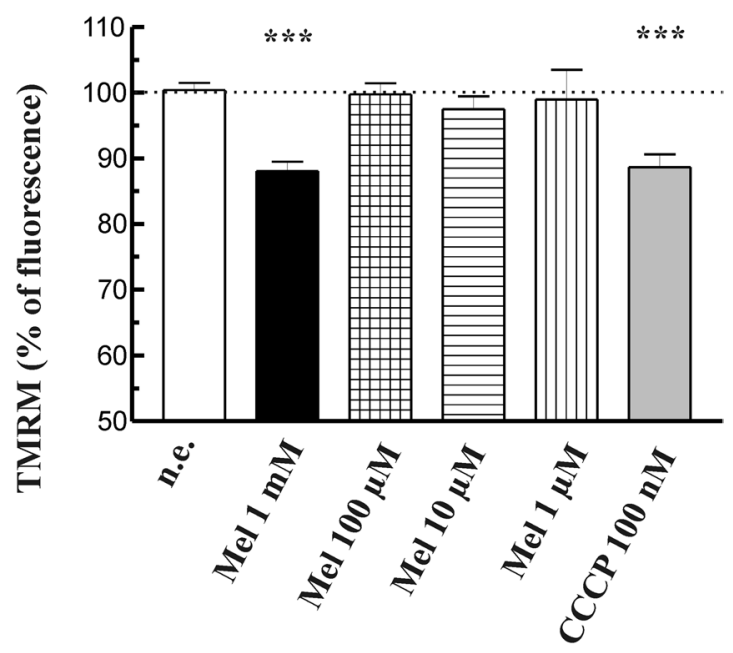

Figure 4. Effect of melatonin on mitochondrial membrane potential. PSC were loaded with the mitochondriaspecific voltage-sensitive dye TMRM. The cells were then incubated during $1 \mathrm{~h}$ in the presence of melatonin $(1 \mathrm{mM}, 100 \mu \mathrm{M}, 10 \mu \mathrm{M}$ or $1 \mu \mathrm{M})$. As a control, different batches of cells were incubated in the presence of the mitochondrial uncoupler CCCP $(100 \mathrm{nM})$. The bars show the changes in $\psi_{\mathrm{m}}$ of treated and non-stimulated (control) cells, and are presented as the mean increase of fluorescence expressed in percentage \pm SEM with respect to non-stimulated cells. A horizontal dotted line represents the value observed in non-stimulated cells (n.e., non-stimulated cells; Mel, melatonin; ***P $<0.001 v s$ non-stimulated cells; $\mathrm{n}=$ four independent experiments).

Effect of melatonin on superoxide dismutase. Superoxide dismutases (SOD) catalyze the dismutation of superoxide anion $\left(\mathrm{O}_{2}^{-}\right)$to $\mathrm{H}_{2} \mathrm{O}_{2}$, which is then catalyzed to innocuous $\mathrm{O}_{2}$ and $\mathrm{H}_{2} \mathrm{O}$ by glutathione peroxidase and catalase. Thus, SOD is involved in the defense system against ROS ${ }^{35}$. Several classes of SOD have been identified: $\mathrm{Cu} / \mathrm{Zn}$ SOD (SOD1), which is localized in cytosol, and MnSOD (SOD2), which is localized in mitochondria $^{36,37}$. We were intereseted in analyzing whether melatonin exerted any affect on SOD. Thus, PSC were incubated during $1 \mathrm{~h}$ with the compound $(1 \mathrm{mM}, 100 \mu \mathrm{M}, 10 \mu \mathrm{M}$ or $1 \mu \mathrm{M})$ and SOD activity was then analyzed. In the presence of melatonin a concentration-dependent decrease in SOD activity was observed (Fig. 6).

We further analyzed the effect of melatonin on SOD and decided to study the protein levels of the enzyme by Western blotting. The results show that PSC that had been incubated with melatonin exhibited lower levels of both SOD1 and SOD2, compared with non-treated cells. The stronger decrease of protein expression was noted for SOD1 (Fig. 7A-D).

Additional studies were carried out to confirm the effect of melatonin on SOD expression. PSC were incubated during $1 \mathrm{~h}$ in the presence of melatonin $(1 \mathrm{mM}, 100 \mu \mathrm{M}, 10 \mu \mathrm{M}$ or $1 \mu \mathrm{M})$ and RT-qPCR of the relative mRNA abundance of SOD1 and SOD2 were performed. In cells treated with melatonin, statistically significant decreases in the mRNA of both proteins were observed (Fig. 7E-F).

Effect of melatonin on the total antioxidant capacity. We additionally evaluated the TAC of PSC. As shown in Fig. 8, the TAC of cells incubated in the presence of melatonin was decreased in comparison with that noted in non-stimulated cells (incubated in the absence of melatonin). The effect did not depend on the concentration of melatonin used. Incubation of PSC with the oxidant $\mathrm{H}_{2} \mathrm{O}_{2}(100 \mu \mathrm{M})$ evoked a statistically significant decrease in TAC compared with non-stimulated cells. These results confirm that melatonin induces changes in the oxidative state of PSC.

\section{Discussion}

It is well known that tumors undergo adaptive responses that lead to resistance and accelerated repopulation. This allows them to overcome doses of radiation and chemotherapy. Resistance can occur following different adaptive responses, which are due to the nature of the tumor cells or to the release of factors by immune cells as well as to participation of other cell types present in the tumor microenvironment ${ }^{9}$. In this line a major contributing factor is the characteristic extensive stromal or fibrotic reaction found in tumors ${ }^{2}$.

In some cancer cells, melatonin itself induces apoptosis ${ }^{10,13,14}$ or aids sensitizing cancer cells to therapy ${ }^{38-41}$. In addition, previous results of our laboratory showed that melatonin modulates viability of PSC. This is of relevance because PSC have been pointed out as major players in stromal formation within tumors ${ }^{17,18}$. Therefore melatonin is emerging as a potential tool in the treatment of cancer.

In this study, we provide further evidences that support a potential role for melatonin in the regulation of PSC proliferation by setting-up a prooxidant environment within the cells, which decreases their viability. The oxidative conditions that we have observed might be based on ROS production together with a decrease in TAC of the cells. The latter might have a basis on a reduction of glutathione levels and a decrease in SOD activity. As a whole, the results that we have obtained can be considered relevant bearing in mind that PSC play major roles in fibrosis developed in pancreatic diseases. 


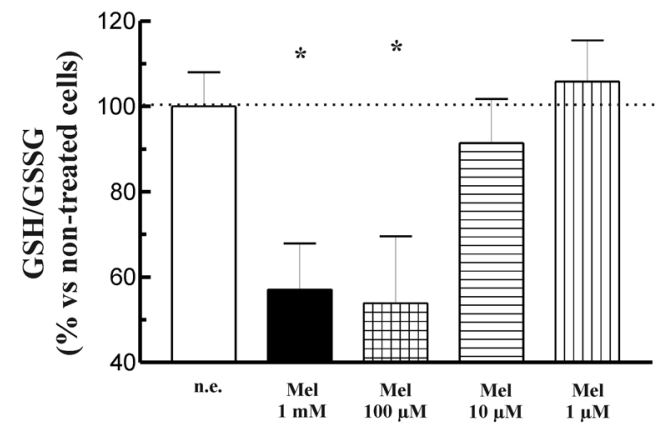

B

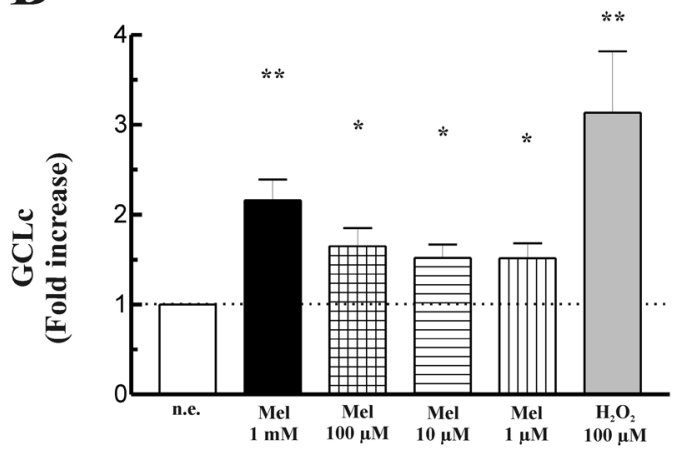

C

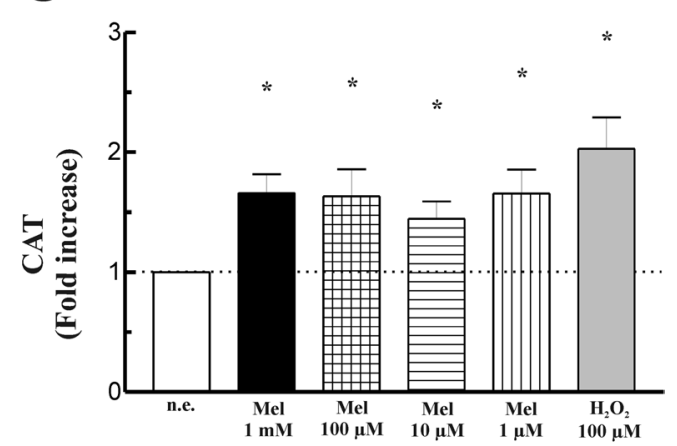

D

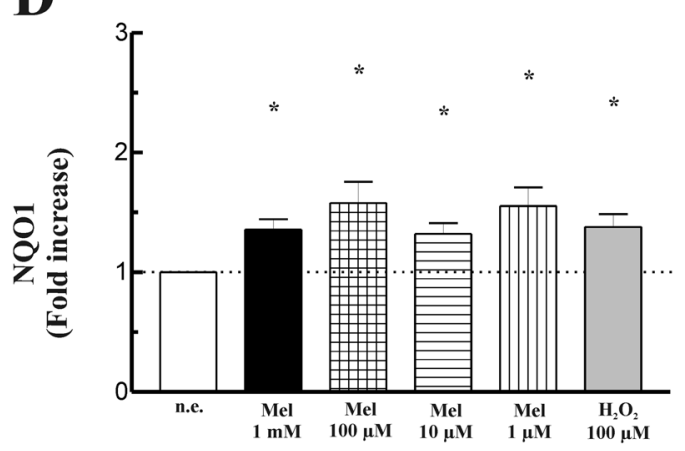

$\mathbf{E}$

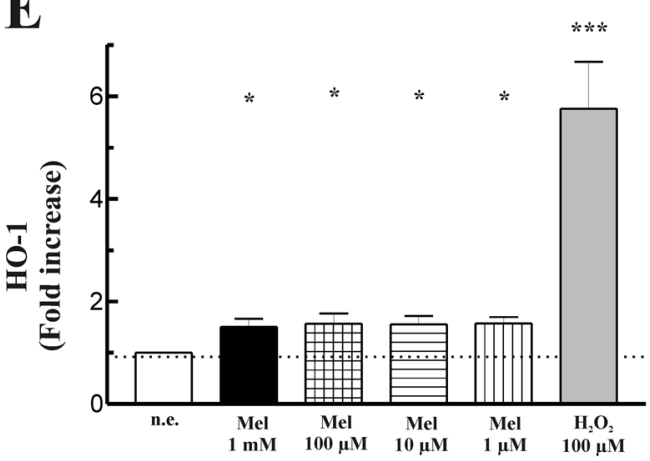

Figure 5. Effect of melatonin on glutathione. (A) PSC were incubated during four $\mathrm{h}$ in the presence of melatonin $(1 \mathrm{mM}, 100 \mu \mathrm{M}, 10 \mu \mathrm{M}$ or $1 \mu \mathrm{M})$, and the effect on glutathione was analyzed. The bars show the mean increase in GSH/GSSG ratio expressed in percentage \pm SEM with respect to non-stimulated cells. (B-D) RTqPCR analysis of Nrf2-target genes glutamate cysteine ligase-catalytic subunit (GClc), catalase (CAT), NAD(P) H quinone oxidoreductase 1 (NQO1) and heme-oxygenase-1 (HO-1) reveals statistically significant increases in the levels of Nrf2-dependent antioxidant enzymes in cells incubated in the presence of melatonin. Incubation of cells with $\mathrm{H}_{2} \mathrm{O}_{2}(100 \mu \mathrm{M})$ also evoked an increase in the expression of all four antioxidant enzymes. Gapdh mRNA was used for normalization. Data are expressed as the mean \pm S.E.M. of the change relative to nonstimulated cells. A horizontal dotted line represents the value observed in non-stimulated cells. Three different cellular preparations were used (n.e., non-stimulated cells; Mel, melatonin; $* P<0.05$; $* * P<0.01$ ).

The drop in PSC viability that we have observed confirms previous studies of our laboratory ${ }^{17,18}$. Interestingly, a decrease in the proliferation of this cellular type would be a helpful maneuver that could help in diminishing the fibrosis present in the pancreas under pathological conditions, especially in tumors.

Maintenance of adequate cellular red-ox equilibrium is critical for cell function and viability ${ }^{42}$. Conversely to the protective role of melatonin against oxidative stress ${ }^{43}$ the compound can also exhibit prooxidant effects, which have been related with a cytotoxic effect ${ }^{28}$. The analysis of the results that we have obtained showed that melatonin induced ROS production. The generation of ROS could be detected in both the cytosol and the mitochondria, but the contribution of $\mathrm{Ca}^{2+}$ was negligible. Participation of mitochondria in ROS generation has been demonstrated $^{44,45}$. These results are in agreement with previous findings of our laboratory, which showed that ROS 


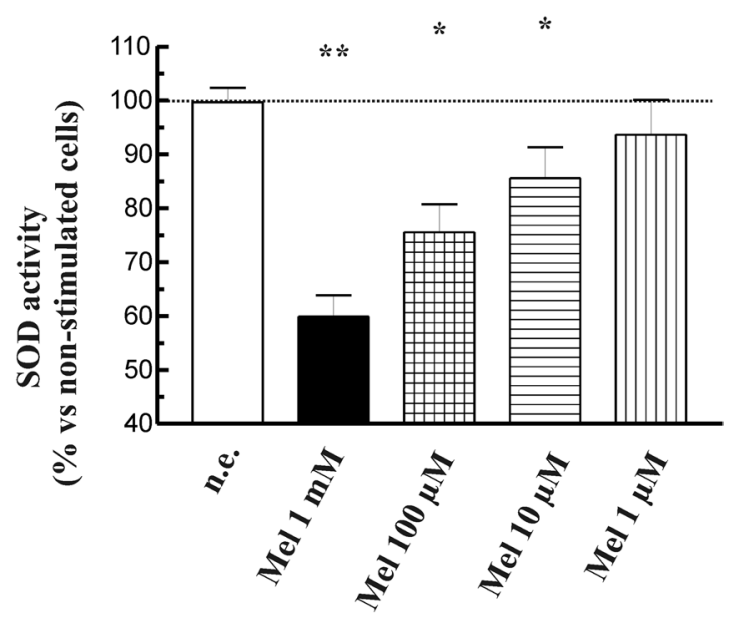

Figure 6. Effect of melatonin on SOD activity. PSC were incubated during $1 \mathrm{~h}$ in the presence of melatonin $(1 \mathrm{mM}, 100 \mu \mathrm{M}, 10 \mu \mathrm{M}$ or $1 \mu \mathrm{M})$. The bars show the mean change of SOD activity expressed in percentage \pm SEM with respect to control (non-stimulated) cells. A horizontal dotted line represents the value observed in non-stimulated cells. Results are representative of five independent experiments (n.e., non-stimulated cells; Mel, melatonin; $* P<0.05$; $* * P<0.01$ vs non-stimulated cells).

production was increased in PSC treated with melatonin ${ }^{17,18}$, and confirm the hypothesis of putative prooxidant actions of melatonin in this cellular type. The present research was conducted in order to further investigate other possible points of action of melatonin to exert its prooxidant effects that could explain its actions on PSC viability.

Our results additionally show that melatonin treatment might be accompanied by oxidation of certain cellular structures. This could be reflected by the increase in the oxidation of cellular proteins that we have noted; however, we could not detect changes in the oxidation of lipids (TBARS). From these observations we could assume that melatonin might differentially affect lipids and proteins within the cell. Besides, it could be possible that certain proteins are more prone to oxidation that lipids upon melatonin treatment. Therefore, melatonin effects on protein redox state could lead to the modulation of metabolic pathways regulated by such proteins, which are activated/inactivated due to changes in their oxidative state.

In addition, impairment of mitochondria leads to ROS generation ${ }^{22,46}$. Our results also show that $\psi_{\mathrm{m}}$ decreased in the presence of melatonin. At this point we could hypothesize that melatonin might affect mitochondrial physiology in PSC. In fact, different studies have suggested that melatonin alters mitochondrial physiology which is related with cell death ${ }^{9,14}$. Moreover, a few studies using cultured cells found that melatonin stimulated ROS generation at pharmacological concentrations (micro-molar to milli-molar range) in several tumor and non-tumor cells; thus, melatonin functioned as a conditional pro-oxidant ${ }^{47}$.

Additional evidences for a disruption by melatonin of the redox balance in PSC derives from the experiments directed to analyze its effect on glutathione. The glutathione system is a major tool used in the defense against damage caused by ROS. A defeat of antioxidant systems, like a decrease in the GSH content, can lead cells to fault in the control ROS production and, therefore, can induce cell damage and death ${ }^{48}$. Our results show that, in the presence of melatonin the ratio GSH/GSSG decreased. This action depended on the concentration of melatonin used. Higher effects were found at $100 \mu \mathrm{M}$ and $1 \mathrm{mM}$ of the indole, whereas no detectable changes were noted in cells treated with $1 \mu \mathrm{M}$ melatonin. The decline in GSH/GSSG ratio that we have noted points towards an increase in oxidized glutathione. This observation might reflect a pro-oxidant action of melatonin. In other words, the decrease in the availability of reduced glutathione could be related with the increase in ROS generation evoked by melatonin. These results are in agreement with previous observations of our laboratory, obtained in human PSC, in which we showed that melatonin evoked concentration-dependent changes in glutathione oxidation ${ }^{18}$. Interestingly, it could be feasible that melatonin might exert the same effects in human cells as those noted in murine cells, thus providing putative beneficial actions of the compound on human health as expected from the results obtained in studies carried out on animal cells.

In another set of experiments we have detected an increase in the expression of the Nrf2-regulated antioxidant enzymes GClc, CAT, HO-1 and NQO1. Specifically, GCLc is involved in glutathione synthesis ${ }^{49}$. Nrf2 is required for systemic protection against redox-mediated injury. Under oxidative conditions the Keap1-ARE (antioxidant response element) pathway is activated via the upregulation of $\mathrm{Nrf}_{2}^{50}$. Melatonin activates this pathway to induce protective antioxidant actions $s^{24,51}$. In our study, the prooxidant conditions evoked by melatonin might activate the Nrf2-regulated pathway in an attempt to counteract the pro-oxidative state that we have observed.

SOD is another enzyme with pivotal role in cellular antioxidant defence ${ }^{52}$. Our results show that SOD activity is decreased in the presence of melatonin. This effect could be explained by a diminished expression of both SOD1 and SOD2, whith a higher effect on SOD1. Our results further suggest that melatonin regulates SOD at the translation level. To our knowledge, this is the first time to show that melatonin decreases the expression of SOD. Findings of other researchers show that melatonin either increases SOD expression ${ }^{53,54}$ or does not induces changes in the levels of these proteins ${ }^{55}$. 
A

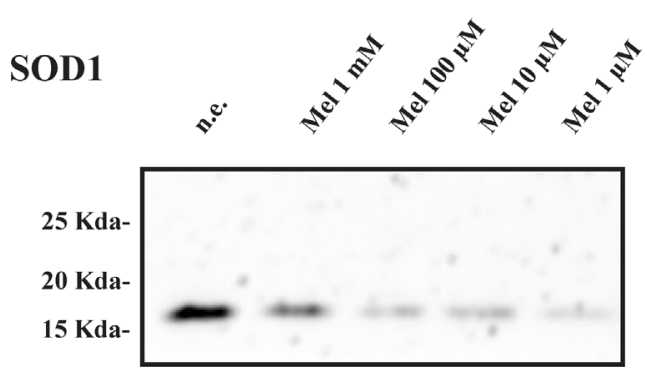

Actin

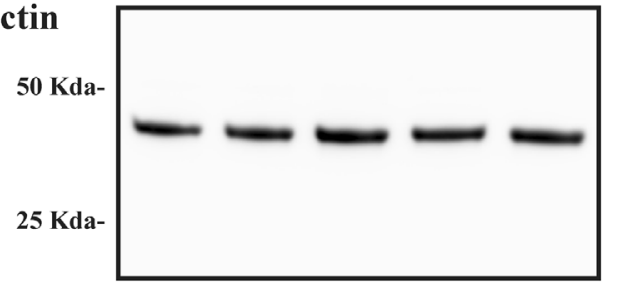

C

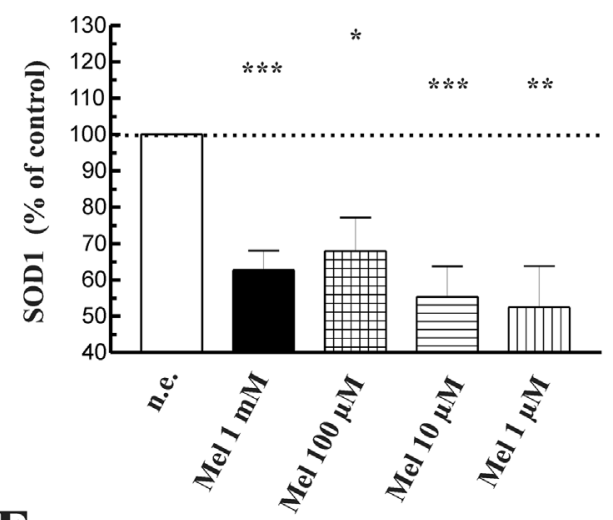

$\mathbf{E}$

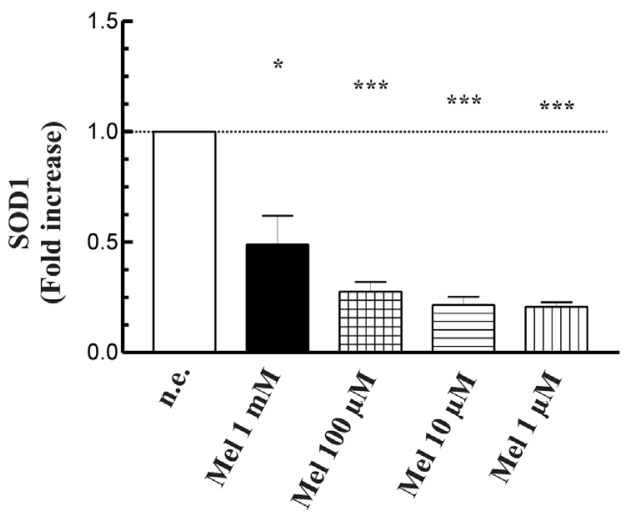

B

SOD2

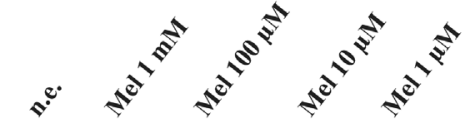

$37 \mathrm{Kda}-$

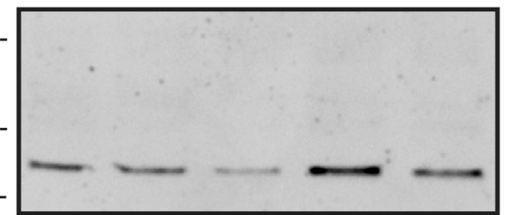

20 Kda-

Actin

50 Kda-

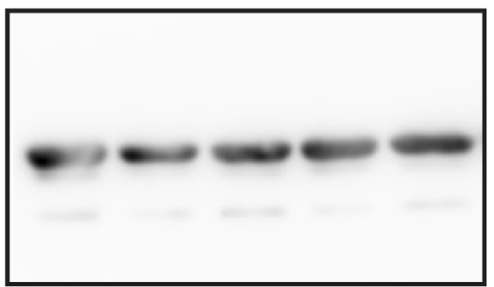

D

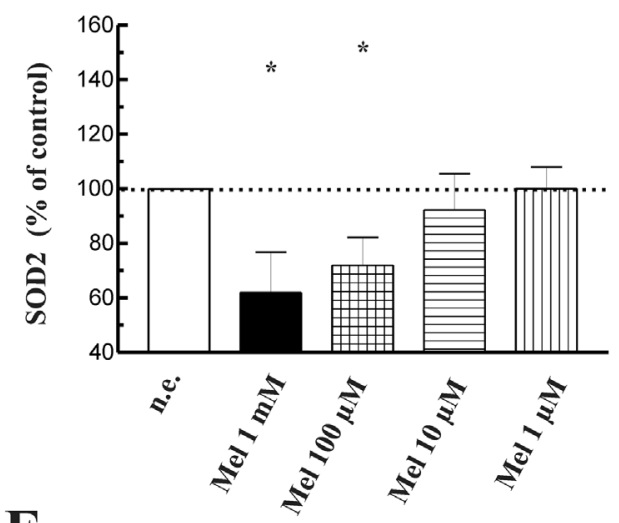

$\mathbf{F}$

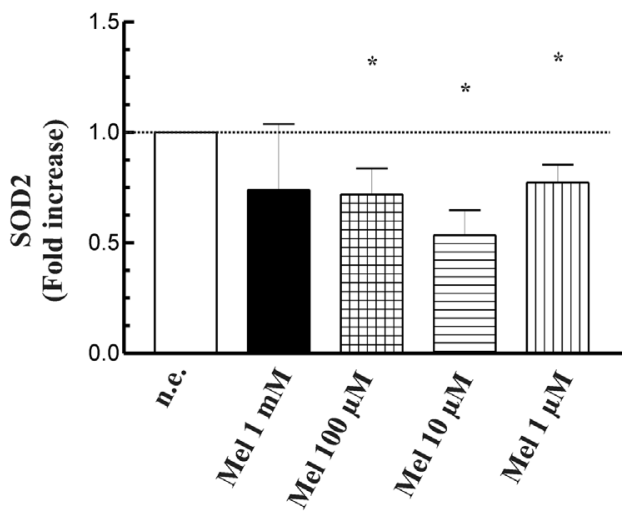

Figure 7. Expression of SOD in PSC treated with melatonin. PSCs were incubated during $1 \mathrm{~h}$ in the absence (Control) or in the presence of the desired concentration of melatonin $(1 \mathrm{mM}, 100 \mu \mathrm{M}, 10 \mu \mathrm{M}$ or $1 \mu \mathrm{M})$. The figure shows representative blots showing the effect of melatonin on the level of the antioxidant enzymes SOD1 (A) and SOD2 (B), evaluated with specific antibodies. The levels of actin were employed as controls to ensure equal loading of proteins. (C and D) The graphs show the quantification of protein expression. A horizontal dotted line represents the value observed in non-stimulated cells. Values are the mean \pm S.E.M. of normalized values expressed as \% of phosphorylation in control (non-stimulated) cells. (E and F) RT-qPCR analysis was performed to detect mRNA levels of SOD1 and SOD2 respectively. The bars show the mean \pm S.E.M. of the change in mRNA levels of each protein relative to non-stimulated cells. Gapdh mRNA was used for normalization. A horizontal dotted line represents the value observed in non-stimulated cells. Three different cellular preparations were used (n.e., non-stimulated cells; Mel, melatonin; $* P<0.05 ; * * P<0.01 ; * * * P<0.001$ $v s$ non-stimulated cells). The experiments shown are representative of three different preparations. 


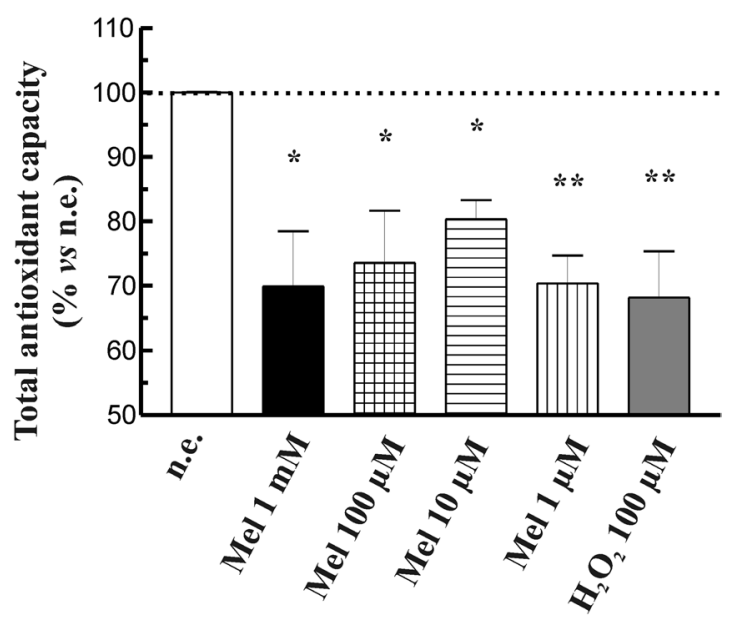

Figure 8. Effect of melatonin on total antioxidant capacity. PSC were incubated with melatonin $(1 \mathrm{mM}, 100 \mu \mathrm{M}$, $10 \mu \mathrm{M}$ or $1 \mu \mathrm{M})$ and then TAC was determined. $\mathrm{H}_{2} \mathrm{O}_{2}(100 \mu \mathrm{M})$ was used as a control of oxidation. Values show the mean \pm S.E.M. of normalized values expressed as $\%$ with respect to non-stimulated cells. A horizontal dotted line represents the value observed in non-stimulated cells. Data are representative of three independent experiments (n.e., non-stimulated cells; Mel, melatonin; $\mathrm{H}_{2} \mathrm{O}_{2}$, hydrogen peroxide; $* P<0.05$; and $* * P<0.01$ vs non-stimulated cells).

Interestinlgy, melatonin exerts prooxidant effects ${ }^{28}$ (Sanchez-Sanchez et al., 2011). A SOD activity under a certain level could lead to diminished antioxidant pretection of the cell that, if is not counteracted by other antioxidant defenses, might lead to prooxidant conditions that could compromise cell function and viability. As a consequence, and taking also into account the effects on glutathione that we have mentioned above, the TAC of the cells should be expected to decrease, as we have observed. Therefore, our results point out that melatonin modulates pivotal points of the cellular antioxidant machinery and leads to prooxidant conditions that could drive the mechanisms involved in PSC viability and/or proliferation. In fact, we have shown previously that melatonin induced changes in the phosphorylation state of members of the mitogen-activated protein kinases family, which are involved in cell proliferation and survival. This resulted in a decrease in cell viability ${ }^{17}$.

The concentrations of melatonin that we have employed are not physiological and fairly fall within the pharmacological range ${ }^{56}$. However, pharmacological concentrations of melatonin have been used in a plethora of studies directed to the study of disease ${ }^{57-59}$, including studies carried out our laboratory ${ }^{14,17,24,60,61}$.

In conclusion, we present evidences that stand out melatonin as a compound with the ability to regulate PSC physiology. Despite the protective role that melatonin exerts in a wide variety of cellular types, here we show that the compound induces pro-oxidative conditions that might have consequences on cell viability. It is noteworthy to bear in mind that the actions of melatonin on cellular physiology might be cell- and context-dependent. Contribution of stellate cells to survival and development of transformed epithelia within the pancreas has been documented $^{62,63}$. Thus, strategies directed to controlling the growth of fibrotic tissue within tumors might be challenging in the treatment of cancer ${ }^{2}$. In this line, our results suggest a probable mechanism by which melatonin modulates fibrosis within the pancreas. Therefore, melatonin could be considered a hopeful aid in the therapy of pancreatic cancer.

Received: 11 December 2019; Accepted: 30 March 2020;

Published online: 14 April 2020

\section{References}

1. Ferdek, P. E. \& Jakubowska, M. A. Biology of pancreatic stellate cells-more than just pancreatic cancer. Pflugers Arch. 469, 1039-1050 (2017).

2. McCarroll, J. A. et al. Role of pancreatic stellate cells in chemoresistance in pancreatic cancer. Front. Physiol. 5, 141 (2014).

3. Hwang, H. J., Oh, M. S., Lee, D. W. \& Kuh, H. J. Multiplex quantitative analysis of stroma-mediated cancer cell invasion, matrix remodeling, and drug response in a 3D co-culture model of pancreatic tumor spheroids and stellate cells. J. Exp. Clin. Cancer Res. 38, 258 (2019).

4. Reiter, R. J., Tan, D. X., Rosales-Corral, S. \& Manchester, L. C. The universal nature, unequal distribution and antioxidant functions of melatonin and its derivatives. Mini Rev. Med. Chem. 13, 373-84 (2013).

5. Favero, G. et al. Promising Antineoplastic Actions of Melatonin. Front. Pharmacol. 9, 1086 (2018).

6. Mahmood, D. Pleiotropic Effects of Melatonin. Drug. Res. (Stuttg.) 69, 65-74 (2019).

7. Slominski, R. M., Reiter, R. J., Schlabritz-Loutsevitch, N., Ostrom, R. S. \& Slominski, A. T. Melatonin membrane receptors in peripheral tissues: distribution and functions. Mol. Cell Endocrinol. 351, 152-66 (2012).

8. Zhang, H. M. \& Zhang, Y. Melatonin: a well-documented antioxidant with conditional pro-oxidant actions. J. Pineal Res. 57, 131-46 (2014).

9. Mortezaee, K. et al. Modulation of apoptosis by melatonin for improving cancer treatment efficiency: An updated review. Life Sci. 228, 228-241 (2019).

10. Farhood, B. et al. Melatonin and cancer: From the promotion of genomic stability to use in cancer treatment. J. Cell Physiol. 234, 5613-5627 (2019).

11. Gu, J. et al. Melatonin inhibits proliferation and invasion via repression of miRNA-155 in glioma cells. Biomed. Pharmacother. 93 , 969-975 (2017). 
12. Liu, Z. et al. Melatonin inhibits colon cancer RKO cell migration by downregulating Rho-associated protein kinase expression via the p38/MAPK signaling pathway. Mol. Med. Rep. 16, 9383-9392 (2017).

13. Pourhanifeh, M. H., Sharifi, M., Reiter, R. J., Davoodabadi, A. \& Asemi, Z. Melatonin and non-small cell lung cancer: new insights into signaling pathways. Cancer Cell Int. 19, 131 (2019).

14. Gonzalez, A., del Castillo-Vaquero, A., Miro-Moran, A., Tapia, J. A. \& Salido, G. M. Melatonin reduces pancreatic tumor cell viability by altering mitochondrial physiology. J. Pineal Res. 50, 250-260 (2011).

15. Leja-Szpak, A., Jaworek, J., Pierzchalski, P. \& Reiter, R. J. Melatonin induces pro-apoptotic signaling pathway in human pancreatic carcinoma cells (PANC-1). J. Pineal Res. 49, 248-255 (2010).

16. Wu, H. et al. Therapeutic opportunities in colorectal cancer: focus on melatonin antioncogenic action. Biomed. Res. Int. 2019, 9740568 (2019).

17. Santofimia-Castaño, P. et al. Melatonin induces calcium mobilization and influences cell proliferation independently of MT1/MT2 receptor activation in rat pancreatic stellate cells. Cell Biol. Toxicol. 31, 95-110 (2015).

18. Estaras, M. et al. Melatonin induces reactive oxygen species generation and changes in glutathione levels and reduces viability in human pancreatic stellate cells. J. Physiol. Biochem. 75, 185-197 (2019).

19. Santofimia-Castaño, P., Salido, G. M. \& González, A. Ebselen alters mitochondrial physiology and reduces viability of rat hippocampal astrocytes. DNA Cell Biol. 32, 147-155 (2013).

20. Gonzalez, A. \& Salido, G.M. Determination of reactive oxygen species production in pancreatic acinar cells. Pancreapedia: Exocrine Pancreas Knowledge Base, https://doi.org/10.3998/panc.2016.32 (2016)

21. Villaverde, A., Parra, V. \& Estévez, M. Oxidative and nitrosative stress induced in myofibrillar proteins by a hydroxyl-radicalgenerating system: impact of nitrite and ascorbate. J. Agric. Food Chem. 62, 2158-2164 (2014).

22. Gonzalez, A., Granados, M. P., Salido, G. M. \& Pariente, J. A. Changes in mitochondrial activity evoked by cholecystokinin in isolated mouse pancreatic acinar cells. Cell Signal. 15, 1039-1048 (2003).

23. Bradford, M. M. A rapid and sensitive method for the quantization of microgram quantities of protein utilizing the principle of protein dye binding. Anal. Biochem. 72, 248-254 (1976).

24. Santofimia-Castaño, P. et al. Melatonin induces the expression of Nrf2-regulated antioxidant enzymes via PKC and Ca2+influx activation in mouse pancreatic acinar cells. Free Radic. Biol. Med. 87, 226-236 (2015).

25. Marques, J. H. M. et al. Melatonin restrains angiogenic factors in triple-negative breast cancer by targeting miR-152-3p: In vivo and in vitro studies. Life Sci. 208, 131-138 (2018).

26. Yun, C. W., Kim, S., Lee, J. H. \& Lee, S. H. Melatonin Promotes Apoptosis of Colorectal Cancer Cells via Superoxide-mediated ER Stress by Inhibiting Cellular Prion Protein Expression. Anticancer Res. 38, 3951-3960 (2018).

27. Nath, R., Raser, K. J., Hajimohammadreza, I. \& Wang, K. K. Thapsigargin induces apoptosis in SH-SY5Y neuroblastoma cells and cerebrocortical cultures. Biochem. Mol. Biol. Int. 43, 197-205 (1997).

28. Sanchez-Sanchez, A. M. et al. Intracellular redox state as determinant for melatonin antiproliferative vs cytotoxic effects in cancer cells. Free Radic. Res. 45, 1333-1341 (2011).

29. Criddle, D. N. Reactive oxygen species, $\mathrm{Ca}(2+)$ stores and acute pancreatitis; a step closer to therapy? Cell Calcium 60, 180-189 (2016).

30. Satoh, T., Enokido, Y., Aoshima, H., Uchiyama, Y. \& Hatanaka, H. Changes in mitochondrial membrane potential during oxidative stress-induced apoptosis in PC12 cells. J. Neurosci. Res. 50, 413-420 (1997).

31. Voronina, S. G., Barrow, S. L., Gerasimenko, O. V., Petersen, O. H. \& Tepikin, A. V. Effects of secretagogues and bile acids on mitochondrial membrane potential of pancreatic acinar cells: comparison of different modes of evaluating DeltaPsim. J. Biol. Chem. 279, 27327-27338 (2004).

32. Garcia-Gimenez, J. L., Roma-Mateo, C., Perez-Machado, G., Peiro-Chova, L. \& Pallardo, F. V. Role of glutathione in the regulation of epigenetic mechanisms in disease. Free Radic. Biol. Med. 112, 36-48 (2017).

33. Schmidlin, C. J., Dodson, M. B., Madhavan, L. \& Zhang, D. D. Redox regulation by NRF2 in aging and disease. Free Radic. Biol. Med. 134, 702-707 (2019).

34. Marinho, H. S., Real, C., Cyrne, L., Soares, H. \& Antunes, F. Hydrogen peroxide sensing, signaling and regulation of transcription factors. Redox Biol. 2, 535-562 (2014).

35. Chaudière, J. \& Ferrari-Iliou, R. Intracellular antioxidants: from chemical to biochemical mechanisms. Food Chem. Toxicol. 37, 949-962 (1999).

36. Milani, P., Gagliardi, S., Cova, E. \& Cereda, C. SOD1 Transcriptional and Posttranscriptional Regulation and Its Potential Implications in ALS. Neurol. Res. Int. 2011, 458427 (2011).

37. Zou, X. et al. Manganese superoxide dismutase (SOD2): is there a center in the universe of mitochondrial redox signaling? J. Bioenerg. Biomembr. 49, 325-333 (2017).

38. Hao, J. et al. Melatonin synergizes BRAF-targeting agent vemurafenib in melanoma treatment by inhibiting iNOS/hTERT signaling and cancer-stem cell traits. J. Exp. Clin. Cancer Res. 38, 48 (2019).

39. Sakatani, A., Sonohara, F. \& Goel, A. Melatonin-mediated downregulation of thymidylate synthase as a novel mechanism for overcoming 5-fluorouracil associated chemoresistance in colorectal cancer cells. Carcinogenesis 40, 422-431 (2019).

40. Wang, Q. et al. Melatonin sensitizes human colorectal cancer cells to $\gamma$-ray ionizing radiation in vitro and in vivo. Int. J. Mol. Sci. 19, E3974 (2018).

41. Zhao, Q., Wang, W. \& Cui, J. Melatonin enhances TNF- $\alpha$-mediated cervical cancer HeLa cells death via suppressing CaMKII/ Parkin/mitophagy axis. Cancer Cell Int. 19, 58 (2019).

42. Chetboun, M. et al. Maintenance of redox state and pancreatic beta-cell function: role of leptin and adiponectin. J. Cell Biochem. 113, 1966-1976 (2012).

43. Bonnefont-Rousselot, D. \& Collin, F. Melatonin: action as antioxidant and potential applications in human disease and aging. Toxicology 278, 55-67 (2010).

44. Granados, M. P., Salido, G. M., Pariente, J. A. \& Gonzalez, A. Generation of ROS in response to CCK-8 stimulation in mouse pancreatic acinar cells. Mitochondrion 3, 285-96 (2004).

45. Pinho, B. R., Reis, S. D., Hartley, R. C., Murphy, M. P. \& Oliveira, J. M. A. Mitochondrial superoxide generation induces a parkinsonian phenotype in zebrafish and huntingtin aggregation in human cells. Free Radic. Biol. Med. 130, 318-327 (2019).

46. Zhou, B. \& Tian, R. Mitochondrial dysfunction in pathophysiology of heart failure. J. Clin. Invest. 128, 3716-3726, https://doi. org/10.1172/JCI120849 (2018).

47. Munik, M. S. \& Ekmekçioglu, C. Prooxidant effects of melatonin: a brief review. Turk. J. Biol. 39, 832-839 (2015).

48. Limon-Pacheco, J. H. \& Gonsebatt, M. E. The glutathione system and its regulation by neurohormone melatonin in the central nervous system. Cent. Nerv. Syst. Agents Med. Chem. 10, 287-297 (2010).

49. Lu, S. C. Glutathione synthesis. Biochim. Biophys. Acta 1830, 3143-3153 (2013).

50. Moon, E. J. \& Giaccia, A. Dual roles of NRF2 in tumor prevention and progression: possible implications in cancer treatment. Free Radic. Biol. Med. 79, 292-299 (2015).

51. Vriend, J. \& Reiter, R. J. The Keap1-Nrf2-antioxidant response element pathway: a review of its regulation by melatonin and the proteasome. Mol. Cell Endocrinol. 401, 213-220 (2015).

52. Hitchler, M. J. \& Domann, F. E. Regulation of CuZnSOD and its redox signaling potential: implications for amyotrophic lateral sclerosis. Antioxid. Redox Signal. 20, 1590-1598 (2014). 
53. Ahmad Hajam, Y., Rai, S., Basheer, M., Ghosh, H. \& Singh, S. Protective Role of Melatonin in Streptozotocin Induced Pancreatic Damages in Diabetic Wistar Rat. Pak. J. Biol. Sci. 21, 423-431 (2018).

54. Col, C., Dinler, K., Hasdemir, O., Buyukasik, O. \& Bugdayci, G. Oxidative stress and lipid peroxidation products: effect of pinealectomy or exogenous melatonin injections on biomarkers of tissue damage during acute pancreatitis. Hepatobiliary Pancreat. Dis. Int. 9, 78-82 (2010).

55. Buyukokuroglu, M. E., Cemek, M., Yurumez, Y., Yavuz, Y. \& Aslan, A. Antioxidative role of melatonin in organophosphate toxicity in rats. Cell Biol. Toxicol. 24, 151-158 (2008).

56. Acuña-Castroviejo, D. et al. Extrapineal melatonin: sources, regulation, and potential functions. Cell Mol. Life Sci. 71, 2997-3025 (2014).

57. Ashrafi, I., Kohram, H. \& Ardabili, F. F. Antioxidative effects of melatonin on kinetics, microscopic and oxidative parameters of cryopreserved bull spermatozoa. Anim. Reprod. Sci. 139, 25-30 (2013).

58. Garcia-Santos, G. et al. Melatonin induces apoptosis in human neuroblastoma cancer cells. J. Pineal Res. 41, 130-135 (2006).

59. Prieto-Domínguez, N. et al. Melatonin enhances sorafenib actions in human hepatocarcinoma cells by inhibiting mTORC1/ p70S6K/HIF-1 $\alpha$ and hypoxia-mediated mitophagy. Oncotarget 8, 91402-91414 (2017).

60. Del Castillo-Vaquero, A., Salido, G. M. \& Gonzalez, A. Melatonin induces calcium release from CCK-8- and thapsigargin-sensitive cytosolic stores in pancreatic AR42J cells. J. Pineal Res. 49, 256-263 (2010).

61. Santofimia-Castaño, P., Ruy, D. C., Salido, G. M. \& Gonzalez, A. Melatonin modulates Ca2+ mobilization and amylase release in response to cholecystokinin octapeptide in mouse pancreatic acinar cells. J. Physiol. Biochem. 69, 897-908 (2013).

62. Mahadevan, D. \& Von Hoff, D. D. Tumor-stroma interactions in pancreatic ductal adenocarcinoma. Mol. Cancer Ther. 6, 1186-1197 (2007).

63. Pothula, S. P. et al. Key role of pancreatic stellate cells in pancreatic cancer. Cancer Lett. 381, 194-200 (2016).

\section{Acknowledgements}

This study was funded by Junta de Extremadura-FEDER (IB16006; GR18070). The funding sources had no role in study design, in the collection, analysis and interpretation of data, in the writing of the report, nor in the decision to submit the paper for publication.

\section{Author contributions}

Antonio Gonzalez: designed the study and wrote the manuscript. Matias Estaras, Salome Martinez-Morcillo, Remigio Martinez, Alfredo García, Mario Estévez, Jose A. Tapia, Noelia Moreno: acquisition and data analysis. Patricia Santofimia-Castaño: designed the primers for PCR. Marcos Pérez-López, María P. Míguez and Vicente Roncero: interpreted and discussed results. Gerardo Blanco, Diego Lopez, Miguel Fernandez-Bermejo, Jose M. Mateos, Daniel Vara: reviewed and corrected the manuscript. Gines M. Salido: suggested discussion parts and corrected the manuscript. All authors have approved and agreed with the submitted version.

\section{Competing interests}

The authors declare that there are no competing interest (there are no financial and non-financial interests that could directly undermine, or be perceived to undermine, the objectivity, integrity and value of this publication).

\section{Additional information}

Correspondence and requests for materials should be addressed to A.G.

Reprints and permissions information is available at www.nature.com/reprints.

Publisher's note Springer Nature remains neutral with regard to jurisdictional claims in published maps and institutional affiliations.

Open Access This article is licensed under a Creative Commons Attribution 4.0 International License, which permits use, sharing, adaptation, distribution and reproduction in any medium or format, as long as you give appropriate credit to the original author(s) and the source, provide a link to the Creative Commons license, and indicate if changes were made. The images or other third party material in this article are included in the article's Creative Commons license, unless indicated otherwise in a credit line to the material. If material is not included in the article's Creative Commons license and your intended use is not permitted by statutory regulation or exceeds the permitted use, you will need to obtain permission directly from the copyright holder. To view a copy of this license, visit http://creativecommons.org/licenses/by/4.0/.

(c) The Author(s) 2020 